\title{
Antiatherogenic Effect of Tiger Nut Tubers (Cyperus esculentus L.) Supplemented Diet in Apolipoprotein E Knockout Mice
}

\author{
Mohsen Zommara ${ }^{1}$ and Katsumi Imaizumi ${ }^{2}$ \\ ${ }^{1}$ Department of Dairy Science, Faculty of Agriculture, Kafrelsheikh University, Kafr \\ El-sheikh 33516, Egypt and ${ }^{2}$ Graduate School of Bioresource and Bioenvironmental \\ Sciences, Department of Bioscience and Biotechnology, Kyushu University, Fukuoka, \\ 6-10-1 Hakozaki, Higashi-ku 812-8581, Japan.
}

$\mathbf{T}$ HE PRESENT study was carried out to evaluate the physiological effect of tiger nut tubers on lipid metabolism and peroxidation stress in apolipoprotein $\mathrm{E}$ knockout $\left(\mathrm{apoE}^{-/-}\right) \mathrm{mice}^{\mathrm{c}}$ Six male and five female mice, 6-7 wk old, was fed on AIN 93G control diet supplemented with $25 \%$ of whole tiger nut tubers powder for $11 \mathrm{wk}$. Measurements were done for plasma, liver, aorta and brain lipid fractions. Peroxidation stress in mice serum and brain, i.e. vitamin $\mathrm{E}$, nitric oxide and Thiobarbituric acid reactive substances (TBARS) were evaluated and aortic valve lesions area was also determined. The obtained results showed that, the type of diet and mice gender did not affect mice growth parameters. Serum and liver lipids were lowered in male mice fed on tiger nut diet than that of control diet. However, the effect of tiger nut diet on the peroxidation parameters was not prominent. The mice fed on chufa-diet resulted in a significant reduction in the aortic arch atherosclerotic lesions in both gender compared to that fed on the basal diet. Finally it can be concluded that tiger nut tubers have antiatherogenic effect and contain a gender dependent factor which regulates lipid metabolism in apoE $\mathrm{E}^{-/-} \mathrm{mice}$.

Keywords: Tiger nut, Chufa, ApoE- knockout mice, Atherosclerosis, Cholesterol, TBARS, Vitamin E, Aorta..

\section{Introduction}

The tiger nut tuber (chufa) is a perennial grass-like edible plant with a slightly sweet and nutty flavor belonging to the sedge family. This plant was originally native to the Mediterranean region but its cultivation has spread to many other warm countries. It is consumed widely in Nigeria, other parts of west and east Africa, parts of Europe particularly Spain as well as in the Arabian Peninsula (Abaejoh et al., 2006). It was an important food in ancient Egypt (Negbi, 1992). Its dry tubers have been found in Pharaohs tombs about 6000 years ago (Zohary, 1986). Nowadays, the tubers are consumed mainly as a refreshing beverage called locally "horchata de tiger nut" (tiger nut milk) in Spain (Pascual et al., 2000). It is also cultivated in Northern Nigeria, Niger, Mali, Senegal, Ghana, and Togo where they are consumed primarily uncooked as a side dish (Omode et al., 1995). The tubers may be consumed as nut or grated and used for ice cream, biscuits and beverage making. Tiger nut has been reported as a wholesome nutritive food. It has long been recognized for their health benefits, as they contain oil $(\sim 25 \%)$ and they are high in oleic acid (about $70 \%$ of total oil), fibers $(\sim 9 \%)$, proteins $(\sim 5 \%)$, minerals $(\sim 1.7 \%)$ and carbohydrates $(\sim$ $43 \%)$. It also contains several micronutrients such as vitamin E, phytosterols, isoflavones, etc. The chemical composition and nutritional value of tiger nut tubers is presented elsewhere (Mokady \& Dolev, 1970, Oladele \& Aina, 2007, Shaker et al., 2009, S'anchez-Zapata et al., 2012 and Zommara $\&$ Imaizumi, 2017). Tiger nut has been found to be good for preventing arteriosclerosis, since its consumption can help prevent heart problems and thrombosis and activate blood circulation (Chukwuma et al., 2010), mainly because its unsaturated fatty acid content is similar to that of olive oil (Linssen et al., 1988) and its arginine is a precursor of nitric oxide which helps the veins to expand (Mart'1nez-Valls, 2003).

Atherosclerosis is the most common causes of death in Western society's; it results from 
complex interactions among multiple genetic and environmental factors. It develops from lowdensity lipoprotein molecules (LDL), the major carrier of cholesterol in human blood. While LDL has an essential physiological role as a vehicle for the delivery of cholesterol to peripheral tissues, increased LDL cholesterol levels are associated with increased risk of cardiovascular disease. Atherosclerosis develops from LDL becoming oxidized by free radicals, particularly oxygen free radicals and nitrogen species produced by vascular cells (Glass \& Witztum, 2001, Stocker \& Keaney, 2004 and Kakadiya, 2009).

Wildmicearehighly resistant to atherosclerosis. However, apolipoprotein (apo) E-knockout mice (apoE $\mathrm{E}^{-/}$mice) have recently been generated by gene targeting (Piedrahita et al., 1992, Breslow, 1996 and Jawieň \& Korbut, 2004). These animals have elevated serum cholesterol levels (400$500 \mathrm{mg} / \mathrm{dl}$ ) and spontaneously develop severe atherosclerosis on low-fat chow diets, which is apparent in mice of only 10 weeks of age (Plamp et al., 1992). They found that, $\mathrm{ApoE}^{-/}$mice fed a high fat diet $(21 \%$ fat and $0.15 \%$ cholesterol) have serum cholesterol levels of approximately $1,500-2,000 \mathrm{mg} / \mathrm{dl}$ and larger lesions at any given time. ApoE is an important legend for the uptake of lipoproteins by many receptors in the LDL receptor gene family, and deficiency of apoE leads to the accumulation of cholesterol ester enriched particles (Piedrahita et al., 1992). Therefore, $\mathrm{ApoE}^{-/-}$mice are considered one of the most relevant models for atherosclerosis since they are hypercholesterolemic and develop spontaneous arterial lesions (Nakashima et al., 1994).

Nitric oxide (NO) is produced in trace quantities by neurons, endothelial cells, platelets and neutrophils in response to homeostatic stimuli (Moncada, 1992 and Nathan, 1992). It was identified as the endothelium relaxing factor (EDRF) responsible for the relaxation of vascular smooth muscle (Ignaro et al., 1987 and Moncada \& Higgs, 1993). Therefor, a disturbance in either production or availability of NO is thought to be responsible for the functional alterations that are associated with endothelial dysfunction and plays a key role in the development of atherosclerotic lesions. NO is a gaseous and unstable substance. The rapid metabolism and short half-life of NO $\left(\mathrm{t}_{1 / 2}=4 \mathrm{sec}\right.$.) poses a considerable obstacle for its analytical assessment in the tissue. It consequently reacts readily with oxygen, yielding nitrite $\left(\mathrm{NO}_{2} \cdot\right)$ or nitrate $\left(\mathrm{NO}_{3} \cdot\right)$ called nitric oxides

J. Sus. Agri. Sci. 43, No. 4 (2017)
(NOx). The direct measurement of plasma nitrite/ nitrate (NOx) value beings would enable us to evaluate the vascular endothelial function as NO release. Kawakatsu et al. (2002) demonstrated that plasma (NOx) was influenced by exogenous factors, aging, and difference of gender, and showed some correlations with hyperglycemic vascular impairments. In comparison with healthy volunteers, it was found that plasma from patient group with coronary artery disease showed a higher NOx value $(\mathrm{P} \leq 0.001)$.

In our previous studies, Tiger nut (chufa) oil and its water and methanol fractions exhibited in vitro anti-lipoperoxidation effect against peroxidation stress initiated by ferrous ions dependent peroxidation stress and in free radical mediated peroxidation by the water soluble initiator 2,2'-azobis (2-aminopropane) dihydrochloride (AAPH) and the lipid soluble free radicals initiator 2,2'-azobis (2,4- dimethylvaleronitrile) (AMVN) in phosphatidylcholine liposomes (Zommara \& El-Shaer, 2001 and Zommara \& Imaizumi, 2017). The aim of this study was therefore to investigate the influence of supplementing a diet with whole powder of tiger nut tubers on serum lipids and atherosclerosis parameters in apoE $\mathrm{E}^{-1-}$ mice. Since there seems to be a gender effect on the serum cholesterol concentration and aortic lesion development in this animal model (Breslow, 1996), both genders were used in the present study.

\section{Materials and Methods}

Animals and diets

Four to five-week-old, male and female, apoE-deficient mice initially engineered at the University of North Carolina (Chapel Hill, NC, USA) (Ni et al., 1998), were purchased from Jackson Laboratory, Bar Harbor, ME, USA. These mice were maintained at the Laboratory of Animal Experiments in Kyushu University Faculty of Medicine (Fukuoka, Japan). The mice were housed individually in a temperaturecontrolled room at $22-25^{\circ} \mathrm{C}$ with a 12 -hr light: dark cycle and acclimatized on a commercially available nonpurified diet (NMF, Oriental Yeast, Tokyo, Japan) for two weeks. Then, the mice were divided into two groups, 6 male and 5 female mice each, and given free access to the AIN-93G based purified diets (Reeves et al., 1993 and AIN, 1997) for 10 weeks. The diet contained (weight percent) casein 20 , olive oil 10, $\alpha$-corn starch 13.2, sucrose 10 , cellulose 5 , vitamin mixture 1 , mineral mixture 3.5 , L-cysteine 0.3 , choline bitartrate 0.25 , tetrabutylhydroquinone (TBHQ) 0.0014 and corn 
starch to 100 . To the control diet was added $25 \%$ of whole powder of tiger nut tubers (from local market at Tanta City, Egypt) at the expense of corn starch and designated as chufa-diet. Food and nonionized water were freely available throughout the experimental period. The average chemical composition of tiger nut tubers are as the fellows: $34 \%$ starch, $25 \%$ oil, $8 \%$ protein, $16 \%$ sucrose, $10 \%$ fiber and $7 \%$ others. The tubers were found to contain 12.4 and $8.5 \mu \mathrm{g} / \mathrm{g}$ of the isoflavons daidzein and genistein, respectively and about $18.6 \mathrm{mg}$ of vitamin E /100 g oil (Zommara \& Imaizumi, 2017). Accordingly, tiger nut-diet was adjusted for its content of oil, protein, corn starch and sucrose. The diets contained about $3606 \mathrm{kcal} / \mathrm{kg}$ diet. The body weight and food intake were recorded every other day. After food was removed for $6 \mathrm{hr}$, the rats were sacrificed by withdrawing blood from the right ventricle under anesthesia with an intraperitoneal injection of sodium pentobarbital ( $5 \mathrm{mg} / \mathrm{g}$ body weight). This experiment was performed under the control of the guidelines for animal experiments of the Faculty of Agriculture and Graduate Course at Kyushu University and law No. 105 and notification No. 6 of the government of Japan.

\section{Tissue preparation}

Blood was collected for serum separation by centrifugation (GEAVI DNA, Sanyodennki Co., Tokyo, Japan) at $3000 \mathrm{rpm}$ for $20 \mathrm{~min}$. The aorta was perfused with $50 \mathrm{ml}$ phosphate buffer saline, PBS ( $\mathrm{pH} 7.4$ ) via a cannula inserted in the right ventricle, allowing unrestricted efflux from an incision in the vena cava. Perfusion was continued with $50 \mathrm{ml}$ of $10 \%$ neutral formalin buffer solution at pH 7.4 (Wako Pure Chemicals, Osaka, Japan), and the heart, aorta and liver were dissected. The bulk of the fat and tissue adhering to the adventitia was dissected from the aorta as much as possible. Liver and aorta were kept at $-70^{\circ} \mathrm{C}$ until needed for further chemical analysis. The heart was fixed in a $20 \%$ neutral formalin buffer solution at pH 7.4 (Wako Pure Chemicals, Osaka, Japan) (Plamp et al., 1992).

\section{Morphometric determination of atherosclerosis}

To determine the cross-sectional lesion volume, hearts containing aortic roots were processed for quantitative atherosclerosis assay of the aortic root using a modification of the methods described by Paigen et al. (1987). Briefly, the heart was cut along a plane between the tip of the two atria and the top half was embedded in paraffin wax. Consecutive sections (10 $\mathrm{mm}$ thick) were prepared from the ascending aorta to the aortic sinus until the aortic tissue disappeared. The sections were mounted on glass slide and stained with elastic Van Gieson and hematoxylin (Ni et al., 1998). Five sections of each heart were selected for intimal area determination; the first and most distal sections to the heart were taken where the aortic valve cusp was barely discernible. From this section, moving to the base of the heart, every other $10 \mathrm{~mm}$ section was also photographed. The intimal area was measured by capturing the image using a video camera mounted on an Olympus LX70 light microscope and analyzed using Adobe Photoshop and Nih image/68K 1.57 software (National Institute of Health, Bethesda, MD, USA) on a Power Macintosh Computer. The mean intimal area was calculated for each animal, and subsequently for each group.

\section{Analytical methods}

Plasma lipids were enzymatically determined with commercially available kits (Cholesterol C Test, Phospholipids B Test and Triglyceride G Test, Wako pure chemicals, Osaka, Japan). Liver lipids were extracted by the method of Folch et al., (1957), and subjected to chemical determination for cholesterol (Sperry \& Webb, 1950), triglycerides (Fletcher, 1968) and phospholipids (Bartlett, 1959). Tiger nut oil phytosterols were determined by GLC as previously described (Nagao, et al., 2001).

\section{Statistical analysis}

All data were expressed as mean $\pm \mathrm{SE}$ and statistical differences were determined by Duncan's multiple range test (Duncan, 1955).

\section{$\underline{\text { Results and Discussion }}$}

Data in Table 1 show the effect of tiger nut (chufa-diet) on growth parameters of male and female apoE $\mathrm{E}^{-/-}$mice. Type of diet did not affect the growth parameters of both mice gender. There were no significant differences among all groups in food intake, body weight gain, food efficiency and liver relative weight. These findings may be explained by the equilibrium in energy content between the control and chufa-diet (about 3606 $\mathrm{kcal} / \mathrm{kg}$ diet), and indicate no deleterious effect of tiger nut on mice metabolism when included in the diet.

Table 2 shows the concentration of blood serum and liver lipids, aorta cholesterol and brain cholesterol and phospholipids of apoE-/- mice fed basal or chufa-diet. As previously mentioned (plamp et al., 1992), the data showed that feeding J. Sus. Agri. Sci. 43, No.4 (2017) 
apoE/- mice on the control diet resulted in elevated tissue cholesterol (824-1016 mg/ dl serum, 8.18$8.60 \mathrm{mg} / \mathrm{g}$ liver) and triglycerides (176-282 mg/ dl serum, (88.4-109.2 mg/g liver) for male mice. These values are extremely high when compared with that obtained from normal male rats (i.e.
Sprague-Dawley rats) fed on normal AIN $76^{\mathrm{TM}}$ diet $(104-111 \mathrm{mg} / \mathrm{dl}$ plasma, $2.1-2.5 \mathrm{mg} / \mathrm{g}$ liver and $122.7-151.3 \mathrm{mg} / \mathrm{dl}$ plasma, $4.2-5.6 \mathrm{mg} / \mathrm{g}$ liver for cholesterol and triglycerides, respectively) (Zommara et al., 1996).

TABLE 1. Effect of chufa diet on growth parameters of apolipoprotein E knockout mice

\begin{tabular}{lrcccc}
\hline \multicolumn{1}{l}{ Groups } & \multicolumn{1}{c}{$\begin{array}{c}\text { Food intake g/ } \\
\text { day }\end{array}$} & $\begin{array}{c}\text { Body weight } \\
\text { gain (g) }\end{array}$ & $\begin{array}{c}\text { Food efficiency } \\
\text { (g gain/g food intake) }\end{array}$ & $\begin{array}{c}\text { Liver } \\
\text { \% }\end{array}$ \\
\hline Control & Male & $4.03 \pm 0.28$ & $10.67 \pm 3.93$ & $0.43 \pm 0.19$ & $4.29 \pm 0.82$ \\
& Female & $3.86 \pm 0.32$ & $9.60 \pm 4.51$ & $0.47 \pm 0.20$ & $3.95 \pm 0.77$ \\
Chufa-diet & & & & \\
& Male & $4.19 \pm 0.22$ & $9.17 \pm 3.06$ & $0.50 \pm 0.16$ & $3.58 \pm 0.24$ \\
& Female & $3.85 \pm 0.06$ & $6.00 \pm 2.35$ & $0.71 \pm 0.21$ & $4.35 \pm 0.82$ \\
\hline
\end{tabular}

Data are the mean \pm SE for 6 male and 5 female mice.

Liver \%, g liver/100 $\mathrm{g}$ body weight.

TABLE 2. Concentration of serum and liver lipids and brain as well as aorta cholesterol of apolipoprotein $\mathbf{E}$ knockout mice fed on chufa diet

\begin{tabular}{lcccc}
\hline \multirow{2}{*}{ Parameter } & \multicolumn{2}{c}{ Control } & \multicolumn{2}{c}{ Chufa-diet } \\
\cline { 2 - 5 } & Male & Female & Female \\
\hline Serum (mg/d) & & & & \\
Cholesterol & $920.0 \pm 96.0^{\mathrm{a}}$ & $684.0 \pm 119.0^{\mathrm{ab}}$ & $531.0 \pm 28.0^{\mathrm{b}}$ & $632.0 \pm 87.0^{\mathrm{b}}$ \\
Triglycerides & $229.0 \pm 53.0^{\mathrm{a}}$ & $107.0 \pm 37.0^{\mathrm{b}}$ & $91.6 \pm 2.4^{\mathrm{b}}$ & $115.0 \pm 24.0^{\mathrm{b}}$ \\
Phospholipids & $439.0 \pm 71.0^{\mathrm{a}}$ & $318.0 \pm 48.0^{\mathrm{ab}}$ & $238.0 \pm 29.0^{\mathrm{b}}$ & $308.0 \pm 50.0^{\mathrm{ab}}$ \\
Liver (mg/g) & & & \\
Cholesterol & $8.39 \pm 0.21^{\mathrm{a}}$ & $5.69 \pm 1.20^{\mathrm{ab}}$ & $4.68 \pm 1.24^{\mathrm{b}}$ & $5.14 \pm 0.85^{\mathrm{b}}$ \\
Triglycerides & $98.8 \pm 10.4^{\mathrm{a}}$ & $40.6 \pm 8.87^{\mathrm{a}}$ & $46.4 \pm 9.63^{\mathrm{b}}$ & $35.8 \pm 6.44^{\mathrm{b}}$ \\
Phospholipids & $25.9 \pm 0.88^{\mathrm{a}}$ & $19.8 \pm 4.47^{\mathrm{a}}$ & $19.6 \pm 3.42^{\mathrm{a}}$ & $20.6 \pm 0.43^{\mathrm{a}}$ \\
Aorta (mg/mg) & & & \\
Cholesterol & & & $2.89 \pm 0.47^{\mathrm{a}}$ & $2.43 \pm 0.43^{\mathrm{a}}$ \\
Brain (mg/g) & $3.60 \pm 0.40^{\mathrm{a}}$ & $2.51 \pm 0.50^{\mathrm{a}}$ & & \\
Cholesterol & & & $16.8 \pm 0.33^{\mathrm{a}}$ & $15.7 \pm 0.48^{\mathrm{a}}$ \\
Phospholipids & $17.0 \pm 0.40^{\mathrm{a}}$ & $16.8 \pm 0.52^{\mathrm{a}}$ & $209.0 \pm 1.6^{\mathrm{ab}}$ & $204.0 \pm 1.01^{\mathrm{b}}$ \\
\hline
\end{tabular}

Data are the mean \pm SE of 6 male and 5 female mice.

${ }^{\mathrm{ab}}$ Means within a raw with unlike superscript are significantly different at $(P<0.05)$.

On the other hand, female mice showed lower tissue lipid concentrations compared to the male one (cholesterol, 565-803 mg/ dl serum, 4.49$6.89 \mathrm{mg} / \mathrm{g}$ liver; triglycerides, (70-144 mg/dl serum, $31.7-49.5 \mathrm{mg} / \mathrm{g}$ liver); that indicates a gender effect. Hypercholesterolemia is a wellestablished risk factor for atherosclerosis and its pathologic complications. The diet supplemented with the tiger nut tubers resulted in a significant reduction in cholesterol and triglycerides by about $42 \%$ and $60 \%$ in blood serum and by about

J. Sus. Agri. Sci. 43, No. 4 (2017)
$44 \%$ and $53 \%$ in liver, respectively compared with the control diet. This effect was obvious in male mice than the female one although there were no significant differences between the two mice groups. Table 2 also show that chufa-diet had no significant differences in aorta and brain cholesterol compared with the control although the aorta from mice fed on chufa-diet tended to have less cholesterol concentration in their aorta.

The hypolipidemic effect of tiger nut may be explained by its content of, polyunsaturated fatty 
acids ( $\sim 9.9 \%$ of total fatty acids), isoflavones (daidzein and genistein (12.4 and $8.5 \mu \mathrm{g} / \mathrm{g}$, respectively) (Zommara \& Imaizumi, 2017) and phytosterols (168 mg/100 oil). Diets enriched with polyunsaturated fatty acids (PUFA) have been recommended for several medical and nutritional aims because of the lipid lowering effects of PUFA in the serum (An et al., 1995 and Schmid \& Woollett, 2003). The cholesterollowering effect may also be linked to the presence of its isoflavones content (kirk et al., 1998, Potter, 1996 and Anderson et al., 1995).

Tiger nut content of phytosterols (mg/ 100g oil) are presented in Table 3. It contains a moderately high amount of phytosterols with a total content of about $168 \mathrm{mg} / 100 \mathrm{~g}$ oil. Plasma phytosterol levels in mammalian tissues are normally very low due to poor absorption from the intestine and faster excretion from the liver compared to cholesterol.

TABLE 3. Phytosterols content in tiger nut oil

\begin{tabular}{lc}
\hline Sterols & mg/ $\mathbf{1 0 0}$ g oil \\
\hline Campesterol & $6.8 \pm 0.17$ \\
Campestanol & $120.1 \pm 2.12$ \\
Stigmasterol & $17.5 \pm 0.38$ \\
$\beta$-sitosterol & $9.3 \pm 0.08$ \\
$\beta$-sitostanol & $14.6 \pm 0.34$ \\
\hline
\end{tabular}

Data are the mean $\pm \mathrm{SE}$ of 3 replicates.

However, phytosterols may have a lot healthy benefits in animals/humans such as the reduction of cholesterol levels with decreaseding risk of coronary heart diseases (Bartnikowska, 2009 and ogbe et al., 2015). Michajlik \& Bartnikowska, (1999) demonstrated that plant sterols inhibit the absorption of dietary cholesterol due to structural similarity, except that they always contain some substitutions at the $\mathrm{C} 24$ position on the sterol side chain. It takes the place of both dietary and endogenous cholesterol in micelles produced in intestinal lumen therefore, less cholesterol is delivered to enterocytes and is incorporated into chylomicrons and VLDLs synthesized in the intestine. However, in case of a high intake of phytosterols it competitively blocks the absorption of cholesterol, and at the same time phytosterols are not absorbed.

The progress of mice atherogenesis was evaluated by several parameters including serum and brain vitamin E content, serum nitrogen oxides (NOx) and brain TBARS (Table 4). The results showed no significant differences in vitamin $\mathrm{E}$ content in mice serum and brain although the serum from chufa-diet fed mice tended to have more vitamin E compared to that fed on the basal diet. Praticò et al., (1998) indicated that oxidative stress is increased in the apo: $\mathrm{E}^{-/-}$mouse, is of a functional importance in the evolution of atherosclerosis and can be suppressed by oral administration of vitamin E. On the other hand, Imaizumi (2011), indicted that the rule of vitamin E ( $\alpha$ - tochopherol) in the progress of atherogensis is inconclusive. As a useful predictor of the endothelial function, mice serum concentration of $\mathrm{NO}_{2} / \mathrm{NO}_{3}$ was significantly lower in female mice than the male fed on the basal diet. However, chufa-diet had no effect on this parameter. The brain of mice fed on chufa-diet resulted in low TBARS concentration compared to male mice fed on the basal diet.

TABLE 4. Some parameters related to peroxidation stress in serum and brain of apolipoprotein $E$ knockout mice fed on chufa diet

\begin{tabular}{lcccc}
\hline Parameter & \multicolumn{2}{c}{ Control } & \multicolumn{2}{c}{ Chufa-diet } \\
\cline { 2 - 5 } & Male & Female & Male & Female \\
\hline Serum & & & & \\
Vitamin E $(\mathrm{mg} / \mathrm{dl})$ & $4.3 \pm 0.7^{\mathrm{ab}}$ & $2.7 \pm 0.5^{\mathrm{a}}$ & $4.7 \pm 0.1^{\mathrm{b}}$ & $3.4^{\mathrm{a}} \pm 0.7^{\mathrm{ab}}$ \\
$\mathrm{NO}_{2} / \mathrm{NO}_{3}(\mu \mathrm{mol})$ & $22.5 \pm 2.4^{\mathrm{a}}$ & $16.7 \pm 0.8^{\mathrm{b}}$ & $18.2 \pm 1.7^{\mathrm{b}}$ & $15.6 \pm 0.7^{\mathrm{b}}$ \\
Brain & & & & \\
Vitamin E(mg/g) & $4.4 \pm 0.5^{\mathrm{a}}$ & $4.1 \pm 0.8^{\mathrm{a}}$ & $5.3 \pm 0.5^{\mathrm{a}}$ & $5.2 \pm 0.3^{\mathrm{a}}$ \\
TBARS $(\mathrm{mmol} / \mathrm{g})$ & $0.60 \pm 0.02^{\mathrm{a}}$ & $0.55 \pm 0.02^{\mathrm{ab}}$ & $0.53 \pm 0.02^{\mathrm{b}}$ & $0.48 \pm 0.03^{\mathrm{b}}$ \\
\hline
\end{tabular}

Data are the mean \pm SE of 6 male and 5 female mice.

${ }^{\mathrm{ab}}$ Means within a raw with unlike superscript are significantly different at $(P<0.05)$. 
As a direct evaluation of the probable antiatherogenic effect of chufa-diet, the aortic arch atherosclerotic lesions $\left(\mathrm{mm}^{2}\right)$ in male and female mice fed the basal or chufa-diet was measured (Fig. 1). Although, no significant differences were found between male and female mice from the two diets group, the female mice tended to have less atherosclerotic lesions compared to the male one. However, the mice fed on chufa-diet resulted in a significant reduction in the aortic arch atherosclerotic lesions in both gender compared with that fed on the basal diet.

Tiger nut oil has a high oleic acid content $(\sim 70 \%)$ and low content of polyunsaturated fatty acid (linoleic acid and linolenic acid) ( 9.9\%) (Zommara \& Imaizumi, 2017). Belewu \& Abodunrin, (2006) demonstrated that tiger nut oil reduces blood low density lipoproteincholesterol (LDL-C) and increases high density lipoprotein-cholesterol (HDL-C), reduces blood triglycerides level and the risk of forming bloody clots, thereby preventing arteriosclerosis. Besides its hypocholesterolemic effects, isoflavones have been reported to modify certain metabolic processes associated with atherosclerotic lesion development, such as inhibiting endothelial cell proliferation and macrophage expression of cytokines (Raines and Ross, 1995).

In conclusion, the obtained results confirmed that tiger nut has a gender dependent hypolipidemic effect and reduces atherosclerotic lesion development in apoE-deficient $\left(\mathrm{apoE}^{-/}\right)$mice. This reduction may be explained by its hypolipidemic effect and reduced peroxidation stress in mice tissue. More investigation is needed to explore the mechanism of its hypolipidemic action, as well as its active fraction(s).

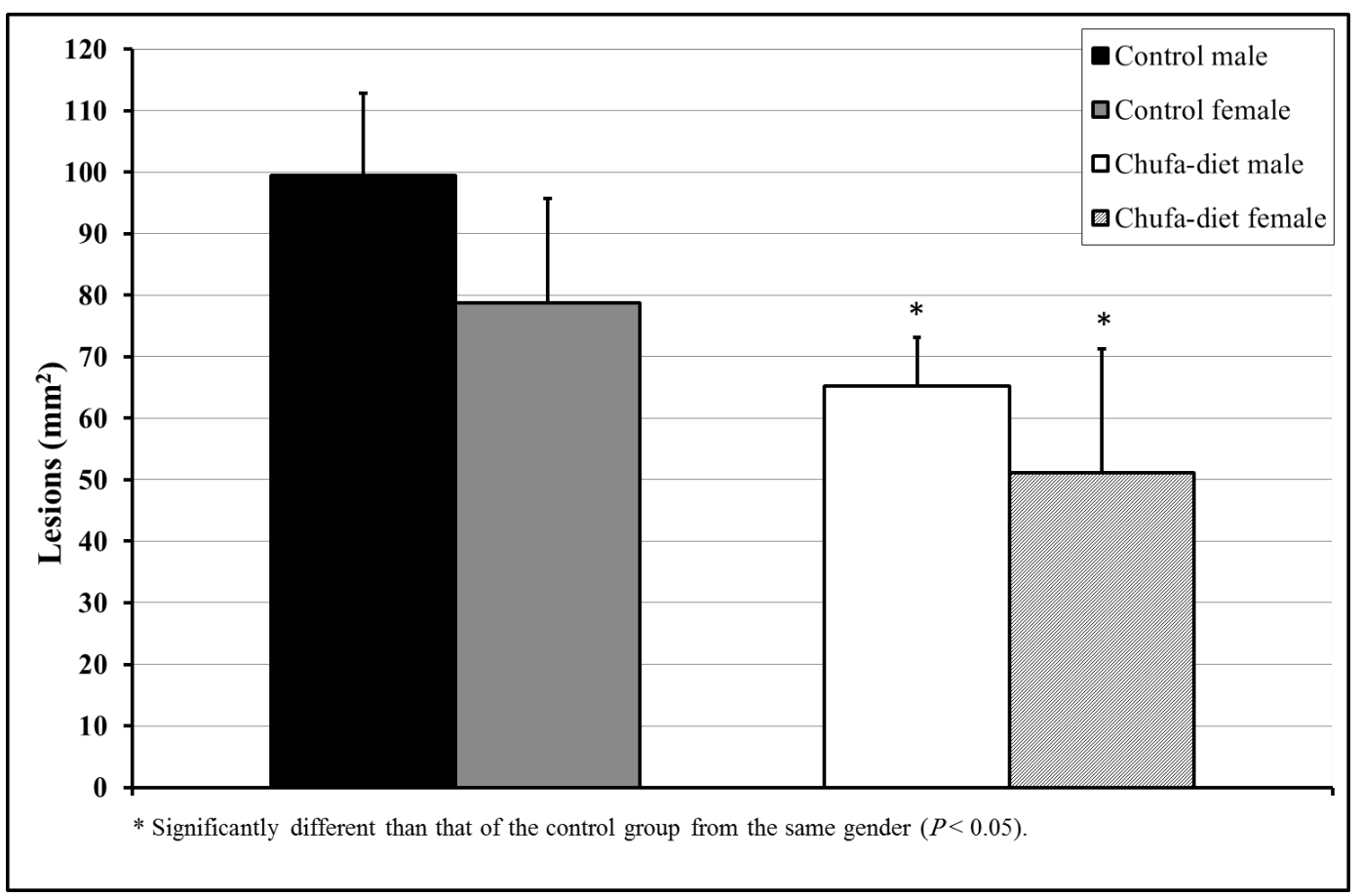

Fig. 1. Atherosclerotic lesions $\left(\mathrm{mm}^{2}\right)$ in the aortic arch of apolipoprotein $\mathbf{E}$ knockout mice fed on chufa diet

Data are mean \pm SD for 6 male and 5 female mice.

\section{References}

Abaejoh, R.; Djomdi, I. and Ndojouenkeu, R. (2006) Characteristics of tigernut (Cyperus esculentus) tubers and their performance in the production of a milky drink. J. Food Process. Preserv., 30, 145163.
American Institute of Nutrition (AIN) (1997) Report of the American Institute of Nutrition and hoc committee on standards for nutritional studies. $J$. Nutr. 107, 1340-1348.

An, B. K.; Tanaka, K. and Ohtani, S. (1995) Effects of various $n-3 / n-6$ fatty acid ratios in diet on lipid 
metabolism in growing chicks. Anim. Sci. Technol., 66, 630-840.

Anderson, J. W., Johnstone, B. M. and Cook-Newwell, M. E. (1995) Meta-analysis of the effects of soy protein intake on serum lipids. N. Engl. J. Med. 333, 276-282.

Bartlett, G. R. (1959) Phosphorus assay in column chromatography. J. Biol. Chem., 234, 466-468.

Bartnikowska, E. (2009) Biological activities of phytosterols with particular attention to their effect on lipid metabolism. Pol. J. Food Nutr. Sci., 59, 105-112.

Belewu, M. A. and Abodunrin, O. A. (2006) Preparation of Kunnu from unexploited rich food source: Tiger nut (Cyperus esculentus). World J. Dairy and Food Sci., 1, 19-21.

Breslow, L. J. (1996) Mouse models of atherosclerosis. Sci. 272, 685-688.

Chukwuma, E. R., Obiama, N. and Christopher, O. I. (2010) The phytochemical composition and some biochemical effect of Nigerian Tigernut (Cyperus esculentus. L) tuber. Pakistan J. Nutr. 9, 709- 715.

Duncan, D. B., (1955) Multi range and multiple F testes. Biometrics, 11, 1-42.

Fletcher, M. J. (1968) A calorimetric method for estimating serum triglycerides. Clin. Chem. Acta 22, 393-397.

Folch, J., Lees, M. and Sloane-Stanley, G. H. (1957) A simple method for the isolation and purification of total lipids from animal tissues. J. Biol. Chem., 226, 497-506.

Glass, K. C. and Witztum, L. J. (2001) Atherosclerosis: The Road Ahead. Cell, 104, 503-516.

Ignarro, L. J., Bug, G. M. and Wood, K. S. (1987) Endothelium derived relaxing factor produced and released from artery and vein is nitric oxide. Proc. Natl. Acad. Sci. USA. 84, 9265-9269.

Imizumi, K. (2011) Diet and atherosclerosis in apolipoprotein E-deficient mice. Biosci., Biotech., Biochem., 75, 1023-1035.

Jawieň, P. J. and Korbut, N. R. (2004) Mouse models of experimental atherosclerosis. J. Physio. Pharma. 55, 503-517.

Kakadiya, J. (2009) Causes, symptoms, pathophysiology and diagnosis of atherosclerosisa review. Pharmacologyonline, 3, 420-442.
Kawakatsu , M., Ishihara, T., Kani, K., Nakagawa, A., Hiura, M., Hazui, H., Okabe, T., Hoshiga, M., Waku, S.; Iida, N. and Hanafuasa, T. (2002) Plasma Nitrate/Nitrite concentration in healthy population and patients with diabetes mellitus - relationships with gender, aging and diabetic complications. Bulletin Osaka Med. College, 48, 1-6.

Kirk, E. A., Sutherland, P., Wang, S. A., Chait, A. and LeBoeuf, R. C. (1998) Dietary isoflavones reduce plasma cholesterol and atherosclerosis in $\mathrm{C} 57 \mathrm{BL} / 6$ mice but not LDL receptor-deficient mice. J. Nutr., 128, 954-959.

Linssen, J. P. H.; Kielman, G. M.; Cozijnsen, J. L. and Pilnik, W. (1988) Comparison of chufa and olive oils. Food Chem., 28, 279-85.

Mart'inez-Valls, J. F. (2003) Scientific analysis of effects of tiger nut on heart diseases and related aspects In: Tiger Nut and Health. Valenciana de Estudios Avanzados. Valencia, Spain.

Michajlik A. and Bartnikowska E. (1999) Lipidy i lipoproteiny osocza. $1^{\text {st }}$ ed., Wydawnictwo Lekarskie PZWL, Warszawa (in Polish).

Mokady S. H. and Dolev A. (1970) Nutritional evaluation of tubers of Cyperus esculenuts L. J. Sci. Food Agric., 21, 211-214.

Moncada, S. (1992) The L-arginine: nitric oxide pathway. Acta Physiol. Scand., 145, 201-227.

Moncada, S. and Higgs, A. (1993) The L-arginine-nitric oxide pathway. N. Engl. J. Med., 329, 2002-2012.

Nagao, K., Sato. M., Takenaka, M., Ando, M., Iwamoto, M. and Imaizumi, K. (2001) Feeding Unsaponifiable compounds from rice bran oil does not alter hepatic mRNA abundance for cholesterol metabolism-related protein in hypercholesterolemic rats. Biosci. Biotechnol. Biochem., 65, 371-377.

Nakashima, Y., Plump, A. S., Raines, E. W., Breslow, J. L. and Ross, R. (1994) ApoE - deficient mice develop lesions of all phases of atherosclerosis throughout the arterial tree. Arterioscler. Thromb., 14, 133-140.

Nathan, C. (1992) Nitric oxide as a secretory product in mammalian cells. FASEB J., 6, 3051-3064.

Negbi, M. (1992) A sweetmeat plant, a perfume plant and their weedy relatives: a chapter in the history of Cyperus esculentus L. and C. rotundus L. Econ. Bot. 46, 64-71.

Ni W-H., Tsuda, Y., Sakono, M. and Imaizumi, K. 
(1998) Dietary soy protein isolate, compared with casein, reduces atherosclerosis in apolipoprotein E-deficient mice. J. Nutr. 128, 1884-1889.

Ogbe, R. J.; Ochalefu, D. O.; Mafulul, S. G. and Olaniru, O. B. (2015) A review on dietary phytosterols: Their occurrence, metabolism and health benefits. Asian J. Plant Sci. Res., 5, 10-21.

Oladele, A.K., and Aina, J.O. (2007) Chemical composition and Functional properties of Flour produced from two varieties of tiger nut. African $J$. of Biotechnol., 6, 2473-2476.

Omode, A. A., Fatoki, O. S. and Olaogun, K. A. (1995) Physicochemical properties of some underexploited and nonconventional oil seeds. J. Agric. Food Chem., 43, 2850-3.

Paigen, B., Morrow, A., Holmes, P. A., Mitchell, D. and Williams, R.A. (1987) Quantitative assessment of atherosclerotic lesions in mice. Atherosclerosis, 68, 231-240

Pascual, B., Maroto, J.V., L'opez-Galarza, S., Sanbautista, A. and Alagarda, J. (2000) Chufa (Cyperus esculentus L. var. sativus Boeck): unconventional crop. Studies related to applications and cultivation. Econ. Bot. 54, 439-48.

Piedrahita, J. A., Zhang, S. H., Hagaman, J. R., Oliver, P. M. and Maeda, N. (1992) Generation of mice carrying a mutant apolipoprotein E gene inactivated by gene targeting in embryonic stem cells. Proc. Natl. Acad. Sci. USA., 89, 4471-4475.

Plamp A.S., Smith J.D., Hayek T. Aalto-setala K.; Walsh A. and Verstuyft J. G. (1992) Severe hypercholesterolemia and atherosclerosis in apolipoprotein E-deficient mice created by homologous recombination in ES cells. Cell, 71, 343-353.

Potter, S. M. (1996) Soy protein and serum lipids. Curr. Opin. Lipidol. 7, 260-264.

Praticò, D., Tangirala, R. K., Rader, D. J., Rokach, J. and Fitzgerald, G.A. (1998) Vitamin E suppresses isoprostane generation in vivo and reduces atherosclerosis in ApoE-deficient mice. Nature Med., 4, 1189-1192.

Raines, E. W. and Ross, R. (1995) Biology of atherosclerotic plaque formation: possible role of growth factors in lesion development and the potential impact of soy. J. Nutr., 125 (suppl.): 624S-630S.

Reeves, P. G., Nielsen, F.H. and Fahey, G.C. Jr.
(1993) AIN-93 purified diets for laboratory rodents: final report of the American Institute of Nutrition ad hoc writing committee on the reformulation of the AIN-76A rodent diet. J. Nutr. 123,1939-1951.

S'anchez-Zapata, E., Fern'andez-L'opez, J. and P'erez-Alvarez, J. A. (2012) Tiger Nut (Cyperus esculentus) commercialization: health aspects, composition, properties, and food applications. Comprehensive Rev. Food Sci. Food Safety, 11, 366-377.

Schmid, K. E. and Woollett, L. A. (2003) Differential effects of polyunsaturated fatty acids on sterol synthesis rates in adult and fetal tissues of the hamster: consequence of altered sterol balance. $\mathrm{Am}$. J. Physiol. Gastrointest. Liver Physiol., 285 (5G): 796-803.

Shaker, M. A. , Gaafar, A. M., Basuny, A. M. and Nassef, S. L. (2009) Chufa Tubers (Cyperus esculentus L.): As a New Source of Food. World Appl. Sci. J. 7, 151-156.

Sperry, W. M. and Webb, M. A. (1950) Revision of the Schoenheimer Sperry method for cholesterol determination. J. Biol. Chem., 187, 97-106.

Stocker, R. and Keaney Jr, J. F. (2004) Role of oxidative modification in atherosclerosis. Physiol. Rev. 84, 1381-1478.

Zohary, D. (1986) The origin and early spread of agriculture in the Old World. In: Barigozzi C, editor. The origin and domestication of cultivated plants. Amsterdam: Elsevier. p. 3-20.

Zommara, M.A. and El-Shaer, M.K. (2001) A comparative study on the resistance to in vitro lipoperoxidation of chufa oil, some vegetable oils and milk fat. Egyptian J. Dairy Sci., 29, 181-192.

Zommara, M. and Imaizumi, K. (2017) In vitro antioxidative activity of chufa tubers (Cyperus esculentus L.) extracts in liposome peroxidation system. J. Sus. Agric. Sci., 43, 69-76.

Zommara, M., Tachibana, N., Sakono, M., Suzuki, Y., Oda, T., Hashiba, H. and Imaizumi, K. (1996) Whey from cultured skim milk decreases serum cholesterol and increase antioxidant enzymes in liver and red blood cells in rats. Nutr., Res., 16, 293-302.

(Received:26 /10 /2017 ; accepted:16/1/2018)

J. Sus. Agri. Sci. 43, No. 4 (2017) 
